$\begin{array}{ll}\text { Research Square } & \begin{array}{l}\text { Preprints are preliminary reports that have not undergone peer review. } \\ \text { They should not be considered conclusive, used to inform clinical practice, } \\ \text { or referenced by the media as validated information. }\end{array}\end{array}$

\title{
Adult Primary Pineal Alveolar Rhabdomyosarcoma With F0X01 Gene Rearrangement and OLIG2 Expression: a Case Report and the Literature Review
}

\section{Lesi Xie}

Department of Pathology, Affiliated Hangzhou First People's Hospital, Zhejiang University School of Medicine https://orcid.org/00000001-5800-0183

\section{Wei Wang}

Affiliated Hangzhou First People's Hospital Zhejiang University School of Medicine: Hangzhou First People's Hospital

\section{Hong Zhou}

Department of Pathology, Affiliated Hangzhou First People's Hospital, Zhejiang University School of Medicine

\section{Zhijiang Han}

Affiliated Hangzhou First People's Hospital Zhejiang University School of Medicine

Jinghong Xu

Department of Pathology, The second Affiliated Hospital, Zhejiang University School of Medicine

Zhihong Xu

Huaxi Kindstar Medical Diagnostics(Sichuan) Company Limited

Jingjing Xiang ( $\square$ xiangcell@163.com )

Affiliated Hangzhou First People's Hospital, Zhejiang University School of Medicine https://orcid.org/0000-0001-6276-6501

\section{Case Report}

Keywords: case report, rhabdomyosarcoma, alveolar rhabdomyosarcoma, pineal gland, OLIG2, FOXO1

Posted Date: May 17th, 2021

DOI: https://doi.org/10.21203/rs.3.rs-520447/v1

License: (1) This work is licensed under a Creative Commons Attribution 4.0 International License. Read Full License

Version of Record: A version of this preprint was published at International Journal of Surgical Pathology on February 21 st, 2022. See the published version at https://doi.org/10.1177/10668969221080076. 


\section{Abstract}

Introduction: Alveolar rhabdomyosarcoma (ARMS) is a common malignant soft tissue tumor in child and adolescents. When diagnosed in adults, it is an aggressive, often fatal disease. Intracranial ARMS in adults is rare, especially in the pineal region.

Case presentation: A 36-year-old Chinese man presented with a 3-month history of dizziness and 1-month history of headache and unsteady walking. Magnetic resonance imaging of the brain revealed a pineal region lesion with obstructive hydrocephalus. He received ventricular-abdominal shunt and endoscopic-assisted pineal lesion resection.

The tumor appears as a solid sheet-like growth of medium-sized round or oval cells with map-like necrosis and some rhabdomyoblasts. Immunohistochemical test revealed that tumor cells were diffusely positive for desmin, myogenin, MyoD1, ALK and CD56. Notably, the tumors were diffusely positive for OLIG2. Fluorescence in situ hybridization confirmed the FOXO-1 gene rearrangement. The final diagnosis of the present case is ARMS of the pineal gland.

Conclusions: We presented an extremely rare case of primary ARMS in adult pineal region particularly with expression of OLIG2 and confirmed by PAX3/7-FOXO1 fusion gene detection.

\section{Introduction}

The 2020 World Health Organization (WHO) classification of bone and soft tissue tumors divides rhabdomyosarcoma (RMS) into embryonic RMS (ERMS), alveolar RMS (ARMS), pleomorphic RMS, and spindle cell RMS. ARMS is charactered by alveolar growth pattern with expression of myogenic markers and specific molecular changes including PAX3/7-FOXO1 [1] and PAX3-NCOA1/2 fusion gene [2]. Recently, some research confirmed that OLIG2 is a new specific marker for ARMS [3,4]. ARMS primarily originating from pineal region is extremely rare. Here we present a primary ARMS of the pineal gland in an adult Chinese man with expression of OLIG2 and confirmed by FOXO1 gene rearrangement.

\section{Case Presentation}

A 36-year-old Chinese man presented with a 3-month history of dizziness and 1-month history of headache and unsteady walking. After admission, enhanced magnetic resonance imaging (MRI) of the brain revealed space-occupying lesions in the pineal region with obstructive hydrocephalus (Figure. 1). He received ventricular-abdominal shunt immediately after admission to relieve the symptoms of acute hydrocephalus and endoscopic-assisted pineal lesion resection 14 days after. The lesion was completely removed and totally sampled for pathological observation. Hematoxylin and eosin (H\&E)-stained sections showed a solid sheet-like growth of neoplastic cells accompanied by map-like necrosis, and rich in thin-walled vessels (Figure. 2A). The tumor cells were mainly medium-sized round or oval cells with pink or clear cytoplasm with clear boundaries. There were some large pink cells with eccentric nuclei resembled rhanbdomyoblasts throughout the tumor. (Figure. 2B). In some areas, the cell density was higher with remarkable atypia (Figure. 2C). In one area, the tumor cells were spindle shaped and arranged in a fusiform weave pattern (Figure. 2D). Immunohistochemical staining revealed that tumor cells were diffusely positive for desmin (Figure. 2E), myogenin (Figure. 2F), MyoD1, Olig2 (Figure. 2G), ALK (clone number D5F3) and INI-1; partially positive for CD 99 and S-100; but negative for CK, EMA, SMA, GFAP, H3K27M, Syn, CgA, NUT, BCOR, SALL4, OCT4, or CD34. The average Ki-67 index was $15-20 \%$ and was $30-35 \%$ in areas with higher cellular density. Fluorescence in situ hybridization (FISH) detection with the FOXO-1 break-apart probe was positive (Figure. $2 \mathrm{H}$ ). No 1p/19q deletion or IDH1/2 gene amplification was detected, and FISH detection with the EWSR1 break-apart probe was negative. The final diagnosis was primary alveolar rhabdomyosarcoma (ARMS) of the pineal gland. The patient received six courses of temozolomide therapy after the operation, and there was no recurrence or metastasis for 8 months after the operation which was confirmed by MRI scanning of the brain.

\section{Discussion}

rhabdomyosarcoma (RMS) is a relatively common malignant tumor of the soft tissue in children and adolescents. Adult RMS that originates in the brain is rare, with most of the cases occur in the cerebrum and cerebellum, and extremely rarely occur in the brain stem, ventricle, meninges, basal ganglia and pineal gland [5]. Primary RMS occurs in the adult pineal region is extremely rare and has only been reported in a few individual cases. This study summarizes recently reported adult RMSs of the pineal region, as shown in Table 1[5-8]. The 2020 WHO classification of bone and soft tissue tumors divides RMS into ERMS, ARMS, pleomorphic RMS, and spindle cell RMS, of which ARMS is the second most common type, accounting for approximately $25 \%$ of all RMSs. The peak age of onset for ARMS is $10-25$ years old, and there is no significant gender difference. It is a highly malignant soft tissue tumor with poor prognosis. The typical 
morphological feature of ARMS is alveolar pattern with the presence of dis-cohesive round cells arranged in nests separated by fibrovascular septa, accompanied by varying numbers of rhabdomyoblasts. The immunohistochemical feature of the tumor cells is a diffuse expression of myogenic markers such as desmin, myogenin, and MyoD1. The rarely seen solid-type cases, like the present case, appear as a completely solid sheet-like growth, lack of fibrovascular septa, and may lack of rhabdomyoblasts, which is difficult to distinguish with various small round cell malignancies. For the really difficulty cases, molecular detection may assist in differential diagnosis. The most common molecular change in ARMS is the PAX3/7-FOXO1 fusion gene, which is seen in about 70\% of the cases, and this type of fusion gene suggests a worse prognosis[1]. The second most common molecular change is the PAX3-NCOA1/2 fusion gene[2]. There were two previously reported cases of primary ARMS in pineal region with $P A X 3-N C O A 1 / 2$ fusion gene [3, 4]. The present case is the first $P A X 3 / 7-F O X O-1$ related primary ARMS in pineal region.

Table 1

Summary of the clinical and pathological features of reported primary pineal RMS in adults.

\begin{tabular}{|c|c|c|c|c|c|c|c|c|c|}
\hline Case & Age & Sex & Morphology & $\mathrm{IHC}$ & Fusion gene & Tumor type & $\begin{array}{l}\text { Post-op } \\
\text { treatment }\end{array}$ & Post-op & $\begin{array}{l}\text { Survival } \\
\text { (months) }\end{array}$ \\
\hline $\begin{array}{l}\text { Laul } \\
\text { (2015) }\end{array}$ & 33 & $\mathrm{~F}$ & $\begin{array}{l}\text { solid sheet-like; } \\
\text { loose round cells } \\
\text { with } \\
\text { rhabdomyoblasts }\end{array}$ & $\begin{array}{l}\text { Desmin, } \\
\text { Myogenin } \\
\text { MyoD1 }\end{array}$ & None-done & $\begin{array}{l}\text { RMS with } \\
\text { alveolar } \\
\text { morphology }\end{array}$ & Chemotherapy & $\begin{array}{l}\text { Intra- } \\
\text { cranial } \\
\text { failure }\end{array}$ & $5, D$ \\
\hline $\begin{array}{l}\text { Scull } \\
(2016)\end{array}$ & 43 & $\mathrm{~F}$ & $\begin{array}{l}\text { solid sheet-like; } \\
\text { spindle cells with } \\
\text { rhabdomyoblasts }\end{array}$ & $\begin{array}{l}\text { Desmin, } \\
\text { Myogenin } \\
\text { MSA }\end{array}$ & None-done & RMS & none & $\begin{array}{l}\text { Rapid } \\
\text { local } \\
\text { recurrence }\end{array}$ & $4, D$ \\
\hline $\begin{array}{l}\text { Jour } \\
\text { (2019) }\end{array}$ & 22 & $\mathrm{~F}$ & $\begin{array}{l}\text { solid sheet-like; } \\
\text { spindle and round } \\
\text { cells, } \\
\text { no } \\
\text { rhabdomyoblasts }\end{array}$ & $\begin{array}{l}\text { Desmin, } \\
\text { Myogenin }\end{array}$ & $\begin{array}{l}\text { PAX3- } \\
\text { NCOA2 }\end{array}$ & ARMS & none & $\begin{array}{l}\text { Recurrence } \\
\text { with spinal } \\
\text { metastasis }\end{array}$ & $14, D$ \\
\hline $\begin{array}{l}\text { Pandey } \\
(2020)\end{array}$ & 44 & $M$ & $\begin{array}{l}\text { Solid sheet-like; } \\
\text { round cells }\end{array}$ & $\begin{array}{l}\text { Desmin, } \\
\text { Myogenin }\end{array}$ & None-done & RMS & $\begin{array}{l}\text { Chemotherapy } \\
+ \\
\text { Radiation }\end{array}$ & $\begin{array}{l}\text { Rapid } \\
\text { local } \\
\text { recurrence }\end{array}$ & $6, D$ \\
\hline $\begin{array}{l}\text { Present } \\
\text { case }\end{array}$ & 36 & M & $\begin{array}{l}\text { Solid sheet-like; } \\
\text { adhesive round } \\
\text { cells with } \\
\text { rhabdomyoblasts; } \\
\text { focal spindle } \\
\text { cells; } \\
\text { some with clear } \\
\text { cytoplasm }\end{array}$ & $\begin{array}{l}\text { Desmin, } \\
\text { Myogenin } \\
\text { MyoD1, } \\
\text { OLIG2 } \\
\text { ALK }\end{array}$ & $\begin{array}{l}\text { PAX3/PXA7- } \\
\text { F0X01 }\end{array}$ & ARMS & Chemotherapy & $\begin{array}{l}\text { No } \\
\text { recurrence }\end{array}$ & $8, A$ \\
\hline
\end{tabular}

OLIG2 is a transcription factor that is required for appropriate development of motor neurons and oligodendrocytes [9]. Accordingly, immunohistochemical staining of OLIG2 is widely used in diagnosis of glial neoplasms and "neuronal neoplasms", including oligodendroglioma, astrocytoma, and ependymoma, medulloblastoma, central neurocytoma and neuroepithelial tumors. Although the tumor cells of the present case do not express GFAP, because the tumor cells diffusely express OLIG2, it was difficult for us to rule out the diagnosis of glial tumors, especially oligodendroglioma. However, subsequent molecular testing showed that there was no deletion of $1 p / 19 q$ and no mutations in the $I D H 1 / 2$ gene, which helped to rule out the diagnosis of glial cell tumors. Recent studies have shown that OLIG2 is not a hindrance to the diagnosis of ARMS but may be a new and specific diagnostic marker for ARMS. Kaleta et al. [3] found that 7 of 45 cases of RMS were positive for OLIG2; it was accompanied by the PAX3/PAX7-FOXO1 fusion gene in 6 cases, and 5 cases with the morphological appearance of ARMS. Raghavan et al. [10] also made similar observations. They studied 73 cases of rhabdomyosarcoma and found that among 28 PAX3/PAX7-FOXO1 fusion gene-positive patients, 27 were positive for OLIG2, and the 
average proportion of positive cells was $49 \%$, with $<5 \%$ in only one patient. Among the 45 PAX3/7-FOXO1 fusion gene-negative cases, only three were positive for OLIG2, and the proportion of positive cells was less than $5 \%$. These studies show that OLIG2 expression is highly correlated with PAX3/7-FOXO1 fusion gene-related ARMS, suggesting that OLIG2 can be used as a specific marker for diagnosis and identification of $P A X 3 / 7-F O X O 1$ fusion gene-related ARMS. Similar with the above studies, our results also indicate that immunohistochemical detection of OLIG2 can serve as a surrogate marker for PAX3/7-FOXO1 fusion gene-related ARMS. In addition, there was one case of PAX3-NCOA2 fusion gene-related ARMS that occurred in the pineal gland of a 12-year-old boy, which also expressed OLIG2[4]. The researchers speculated that because PAX3 is an important transcription factor in the development of the central nervous system, related fusion genes activate a variety of neurodevelopment-related genes, including neurodevelopment-related OLIG2, leading to the up-regulation of OLIG2 expression.

\section{Conclusion}

To summarize, we presented the first case of primary ARMS in adult pineal region confirmed by PAX3/7-FOXO1 fusion gene detection and particularly with expression of OLIG2. The expression of OLIG2 can easily mislead us to the diagnosis of glial cell tumors or other tumors. Therefore, extra attention should be paid during diagnosis and differentiation in central nervous system. Be aware of the possible diagnosis of OLIG2-positive ARMS or other possible tumors may avoid misdiagnosis of round-cell tumors of the central nervous system.

\section{Abbreviations}

WHO: World Health Organization; RMS: rhabdomyosarcoma; ERMS: embryonic rhabdomyosarcoma; ARMS: alveolar rhabdomyosarcoma; MRI: magnetic resonance imaging; ALK: anaplastic lymphoma kinase; CK: cytokeratin; EMA: epithelial membrane antigen; SMA: smooth muscle actin; GFAP: glial fibrillary acidic protein; Syn: Synaptophysin; CgA: chromogranin A; FISH: fluorescence in situ hybridization.

\section{Declarations}

\section{Ethics approval and consent to participate}

The institutional review board of Affiliated Hangzhou First People's Hospital, Zhejiang University School of Medicine approved the study.

\section{Consent for publication}

The consent for publication of images and information about the patient from his wife has been obtained.

\section{Availability of data and materials}

All data generated or analyzed during this study are included in this article and its supplementary information files.

\section{Competing interests}

The authors declare that they have no competing interests.

\section{Funding}

Not applicable.

\section{Authors' contributions}

LSX, HZJ, WW, HZ and ZHX: figures and tables collection/analysis and all cowrite the manuscript. WW, $\mathrm{HZ}$ and ZHX: immunohistochemical tests and FISH tests. JHX and JJX: reviewing and editing of the manuscript. All authors read and approved the final manuscript.

\section{Acknowledgements}

Not applicable.

\section{References}


1. Davicioni E, Anderson MJ, Finckenstein FG, Lynch JC, Qualman SJ, Shimada H, Schofield DE, Buckley JD, Meyer WH, Sorensen PH and others. Molecular classification of rhabdomyosarcoma-genotypic and phenotypic determinants of diagnosis: a report from the Children's Oncology Group. Am J Pathol 2009;174(2):550-64. http://doi.org/10.2353/ajpath.2009.080631

2. Yoshida H, Miyachi M, Sakamoto K, Ouchi K, Yagyu S, Kikuchi K, Kuwahara Y, Tsuchiya K, Imamura T, Iehara T and others. PAX3NCOA2 fusion gene has a dual role in promoting the proliferation and inhibiting the myogenic differentiation of rhabdomyosarcoma cells. Oncogene 2014;33(49):5601-8. http://doi.org/10.1093/jnen/nlz083

3. Kaleta M, Wakulinska A, Karkucinska-Wieckowska A, Dembowska-Baginska B, Grajkowska W, Pronicki M, Lastowska M. OLIG2 is a novel immunohistochemical marker associated with the presence of PAX3/7-FOX01 translocation in rhabdomyosarcomas. Diagn Pathol 2019;14(1):103. http://doi.org/10.1186/s13000-019-0883-4

4. Tauziede-Espariat A, Beccaria K, Pierron G, Guillemot D, Hasty L, Abbou S, Dangouloff-Ros V, Boddaert N, Chretien F, Varlet P and others. Pineal alveolar rhabdomyosarcoma with PAX3:NCOA2 fusion inducing OLIG2 sexpression, a potential pitfall in the central nervous system. Histopathology 2021. http://doi.org/10.1111/his.14364

5. Scull C, Amar S, Feiz-Erfan I, Dave H, Gridley D. Adult Onset Primary Pineal Rhabdomyosarcoma. J Clin Oncol 2016;34(15):e137-40. http://doi.org/10.1200/JC0.2013.50.8036

6. Lau SK, Cykowski MD, Desai S, Cao Y, Fuller GN, Bruner J, Okazaki I. Primary rhabdomyosarcoma of the pineal gland. Am J Clin Pathol 2015;143(5):728-33. http://doi.org/10.1309/AJCP9ZON4ZIHODIG

7. Jour G, Serrano J, Koelsche C, Jones D, von Deimling A, Allen J, Snuderl M. Primary CNS Alveolar Rhabdomyosarcoma: Importance of Epigenetic and Transcriptomic Assays for Accurate Diagnosis. J Neuropathol Exp Neurol 2019;78(11):1073-1075. http://doi.org/10.1093/jnen/nlz083

8. Pandey L, Joseph D, Arora R, Singh A, Kassim N, Pasricha R, Gupta M. Primary pineal rhabdomyosarcoma in an adult male patient: A rare presentation and review of the literature. Clin Neurol Neurosurg 2020;196:106044. http://doi.org/10.1016/j.clineuro.2020.106044

9. Zhou Q, Anderson DJ. The bHLH transcription factors OLIG2 and OLIG1 couple neuronal and glial subtype Cell 2002;109(1):61-73. http://doi.org/10.1016/s0092-8674(02)00677-3

10. Raghavan SS, Mooney KL, Folpe AL, Charville GW. OLIG2 is a marker of the fusion protein-driven neurodevelopmental transcriptional signature in alveolar rhabdomyosarcoma. Hum Pathol 2019;91:77-85. http://doi.org/10.1016/j.humpath.2019.07.003

\section{Figures}
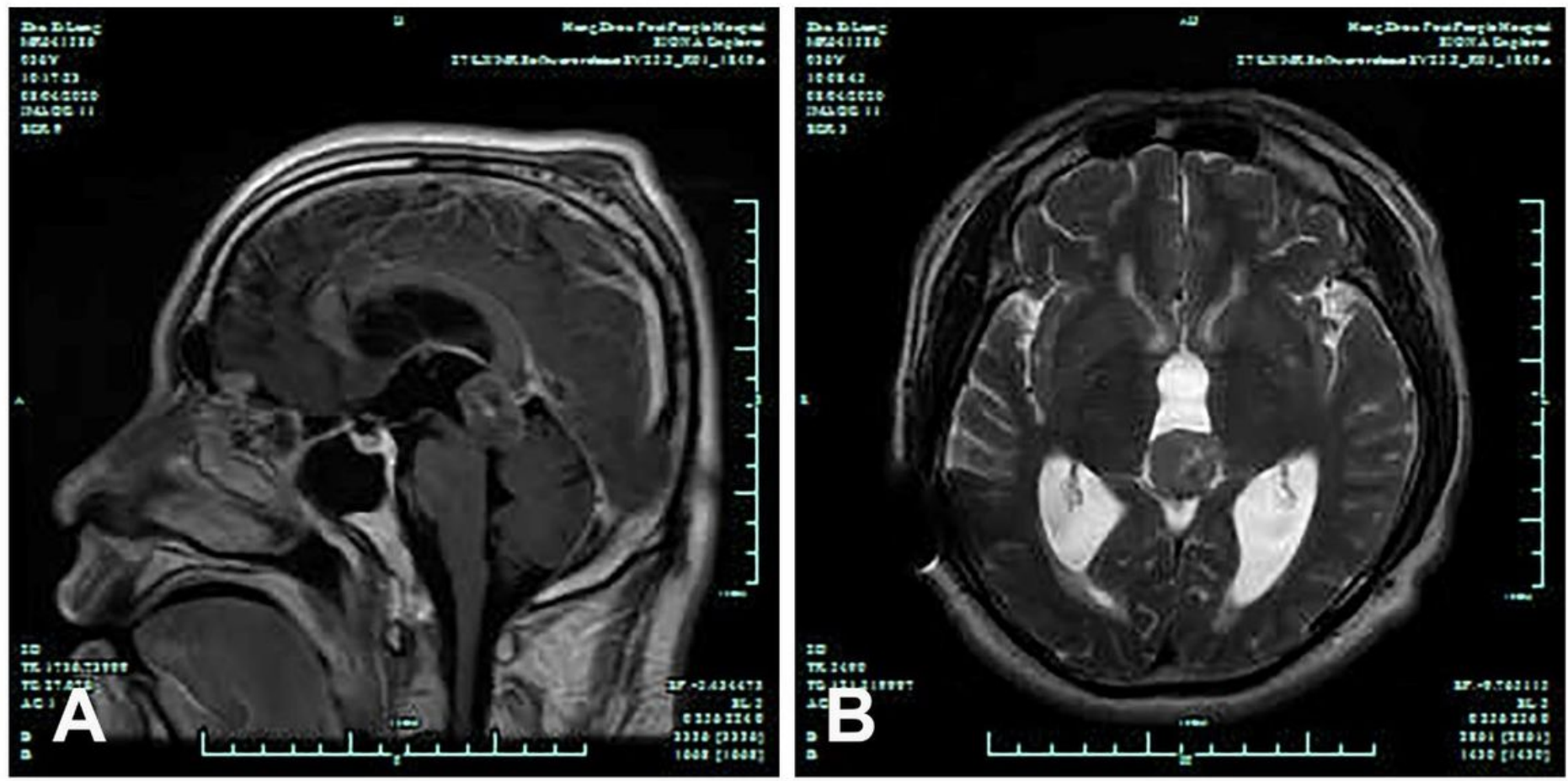

Figure 1 
Images of enhanced MRI of the head. A: Axial contrast-enhanced T1-weighted image shows slight enhanced lesion in the pineal region. B: Axial T2-weighted image shows quasi-circular isointense lesion in the pineal region, with strip-like hyperintensities inside, but the main body is not obviously enhanced. MRI, magnetic resonance imaging

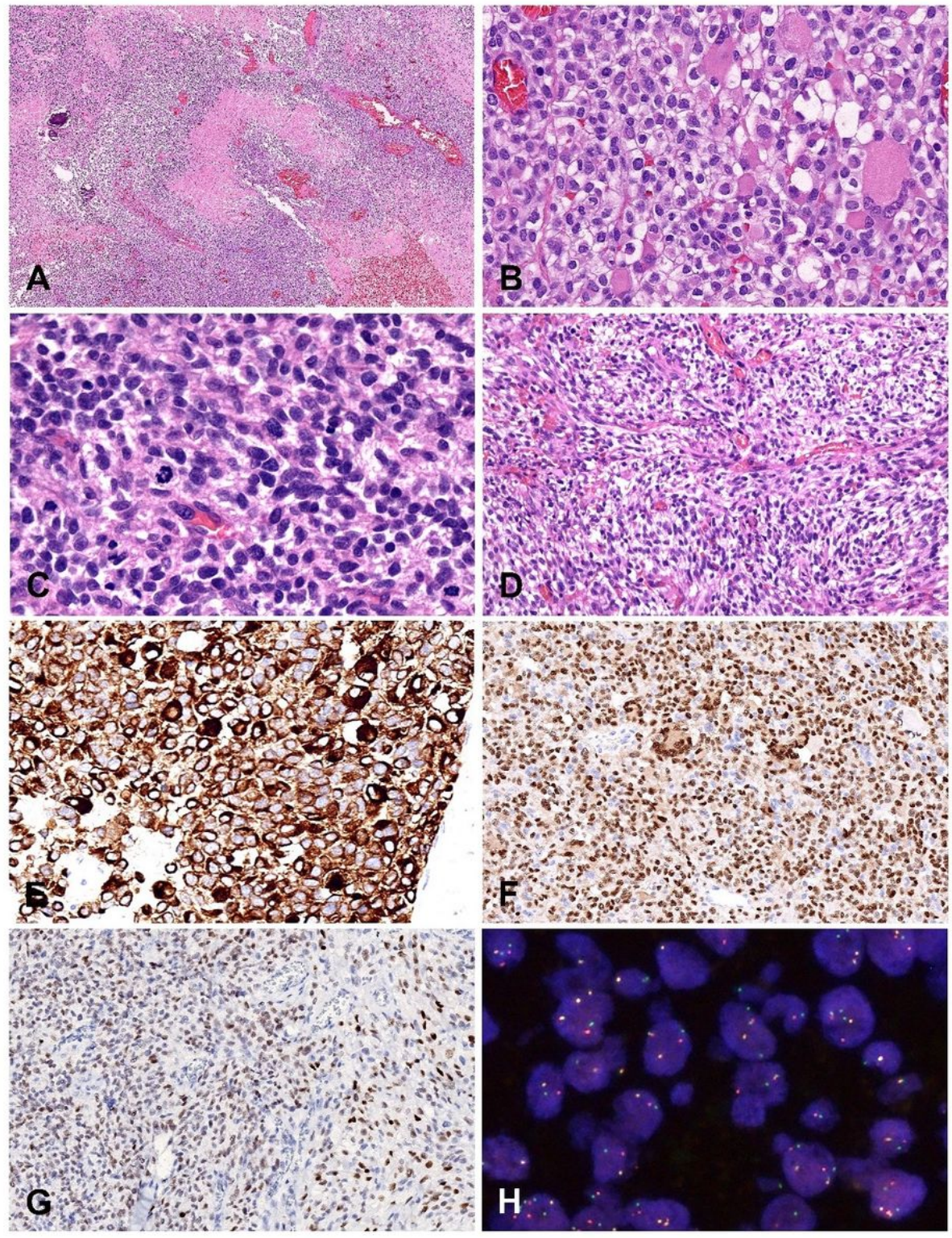

\section{Figure 2}

A: The tumor grows in a solid sheet-like pattern, accompanied by multifocal map-like necrosis and hemorrhage. A small number of gravelshaped calcifications can be seen at the peripheral areas. H\&E staining, 10x magnification. B: The neoplastic cells are relatively uniform with slight atypia. Medium-sized round or oval cells are adherent to each other with clear boundaries. The cytoplasm is stained light pink or clear and bright. The nuclei are round, with fine chromatin and tiny nucleoli. Large rhabdomyoblasts with eccentric nuclei and abundant pink-stained cytoplasm and one multinucleated rhanbdomyoblasts can be seen. H\&E staining, 400× magnification. C: An area with higher cellular density composed of significantly atypical darkly-stained small to medium-sized tumor cells with multiple mitotic figures. H\&E staining, 200× D: An area of short spindle-shaped tumor cells with pink or clear cytoplasm arranged in a weave or storiform pattern. H\&E staining, 400×magnification. E: Desmin immunohistochemical staining shows diffuse and strong cytoplasmic positivity in tumor cells. Rhabdomyoblasts are more strongly positive. H\&E staining, 400×magnification. F: Myogenin immunohistochemical staining shows diffuse nuclear positivity in tumor cells. Rhabdomyoblasts and multinucleated rhabdomyoblasts are also strongly positive. H\&E staining, 200×magnification. G: OLIG2 immunohistochemical staining shows diffuse nuclear positivity in tumor cells. H\&E staining, 200xmagnification. H: FISH detection with the FOXO1 break-apart probe shows separated red and green signals appearing in some tumor cells. H\&E, hematoxylin and eosin; FISH, fluorescence in situ hybridization. 


\section{Supplementary Files}

This is a list of supplementary files associated with this preprint. Click to download.

- CAREchecklist.pdf 